The discovery that the bacillus of rat leprosy can be transmitted to the Syrian hamster, has been followed by the announcement from Palestine that this species can be similarly infected with the causative organism of human leprosy. This work should provide the basis of a new attack on the problems of this disease, and, in particular, make possible the experimental study of the treatment of leprosy by chemotherapeutic methods.
A few only of the subjects dealt with in the report have been selected for notice in this review : for a fuller picture of the Council's activities reference must be made to the original. It may be mentioned that full titles and references to the original papers published by members of the Council's staff and other investigators are given throughout the report, so that those interested can easily obtain the further details they require.

\title{
The Linnæan Tradition
}

$F^{0}$ OUNDED ten years after the death of the celebrated Linnæus, the Linnean Society of London has for the past hundred and fifty years carried on the work he initiated in systematic botany and zoology. The anniversary was celebrated in London by appropriate meetings on May 24-27. Without any doubt the founding of the Society was due to the presence of the Linnæan Collections in England in 1784, in which year they had been received by purchase from Linnæus's widow by James Edward Smith, a medical student then twenty-four years of age. That close contact with the materials used by the great Swede resulted in the English naturalists adhering very closely to what may be called the Linnæan tradition; and although the systems used by Linnæus have been greatly changed or superseded, it is significant that his authority and influence are still felt strongly to-day.

The tradition left by Linnæus was indeed a great and a worthy one. Despite the carping criticisms of certain historians, there is no doubt at all that Linnæus wrought a great and fundamental work in both botany and zoology. Concentrating his efforts on the classification and description of plants and animals, he did the task most needed for his time; leaving a vast body of completed work, and, as the result of his deep and sincere thought, methods which are followed in the main by taxonomists to-day. Looking across two centuries, we can visualize that short sturdily built man with his keen-sighted brown eyes and his open and pleasant face, who worked from boyhood to old age with singleness of purpose towards one objective-to know and classify all forms of living organisms. No living organism can be named correctly until it is known; none known properly until it is classified correctly.

Linnæus's achievements in botany and zoology can be gauged rightly only when considered in relation to the states of those sciences at the time when he worked. He came at a time when Western naturalists had succeeded in disentangling themselves from the ancient authority and superstition that had clung to them long after the Renaissance. Men had turned from the authority of books to study Nature; from travels and exploration more new plants and animals were becoming known each succeeding year; attempts were being made to present in systematic form the knowledge then extant; but the net result had been a chaos in which each worker had put forward his own ideas of system and nomenclature.

Coming at the very time when he was urgently needed, Linnæus, clear-headed, practical, imaginative, resolved that chaos into order. Although so early as 1738 he had published in "Classes plantarum" a sketch of a natural system in botany, and throughout his life continued to elaborate it, his botanical works were always arranged according to the sexual system, which he had devised when he was twenty-four years of age. His reason for adhering to that system was a sound one: at the time he worked, an insufficient number of plants were known to found properly a natural system. Nevertheless, his own system brought together automatically some of the natural groups ; and when the rise of the natural system began with the work of the de Jussieus, Robert Brown and others, much of Linnæus's work on genera and species still held good. In zoology, also, Linnæus's influence continues in spite of changes of system.

The Linnean Society's early history reflects most clearly that almost religious adherence to the Linnæan tradition; but the rise of the natural system in botany, the impact of the Darwinian theory of natural selection, the influence of the great school of German physiological botanists, or the specialistic developments of modern biology, have not obliterated that tradition. None of these waves of influence could or can sweep away the ultimate necessity of presenting the facts of Nature in taxonomic form. Under his will, Darwin left a sum of money to be devoted to the 
compilation of a great index for the use of taxonomists, the "Index Kewensis"; the aim of the German physiologists was to find a better basis of taxonomy (one of the negative results of which is that to-day real systematic botany is but scantily touched upon in British universities); and the efforts of the ecologists, geneticists and cytologists can have but one real object-the ultimate reclassification of living organisms.

Among the tendencies of the present time, it is possible to detect an impatience with the existing forms of taxonomy; but any attempt to alter such forms without very profound consideration and fair trial would seem likely to lead to a chaos similar to that from which Linnæus reseued the learned world. Often without being able to read with any ease the Latin works of the older naturalists, some of the modern workers appear to be inclined to cut adrift entirely from the past. The remedy surely lies in a more careful consideration of the philosophical ideas upon which all taxonomy must be based.

\section{A Discontinued Darwin Medal}

\section{By T. E. James}

$\mathrm{T}$ HE rise and mutual development in Great Britain of provincial natural history and literary societies, microscopical clubs and field clubs is one of the stories of nineteenth century science that scarcely requires iteration. Yet in regard to one of these, the Midland Union of Natural History Societies, an amalgamation of 1878, due in the main to the efforts of Mr. Lawson Tait, F.R.C.S., of Birmingham, there is a connexion of Darwinian interest in the Union's institution of a Darwin Medal, which in course of time has lapsed in award, and possibly is now altogether out of mind.

The medal bore on the obverse the portrait-bust of Charles Darwin in bas-relief and the reverse a branch of coral ; while the medal itself was the work of Joseph Moore(1817-1901), a well-known medallistsculptor and die-sinker in Birmingham.* Why the award of this medal ceased will be considered presently. Apart from the Royal Society's Darwin Medal (the first award of which was not made until 1890 ), there would appear now to be no medallic gift in Great Britain which periodically com. memorates the researches of the great naturalist in this way.

The idea of an amalgamation of the numerous scientific and literary societies already existing in various parts of the Midland counties took practical shape in 1878 as above mentioned, and a journal called the Midland Naturalist was started as the organ of the Union; the journal appeared successfully down to the end of the year 1893. It was an effective and highly popular medium of intercommunication, but like other official fusions of the period, strength of membership carried latent weaknesses. The magazine eventually became an onerous task, its issue resting on the efforts of the zealous minority.

Returning to the Darwin Medal of the Midland

- Joseph Moore also designed a medal for the British Association meeting at Birmingham in 1849 and at Cheltenham in 1856.
Union, it appears that at the annual meeting held in 1880 at Nottingham, a suggestion was made by Mr. W. Jerome Harrison for the foundation of a yearly prize which should have as an objective the encouragement of original research connected with the natural history of the Midlands. Regarded favourably, it was unanimously agreed to institute an annual Darwin Prize of the value of $£ 10$, to include a gold medal denominated the Darwin Medal, for a paper embodying original research contributed by a member of the Union for publication in the Midland Naturalist. Incidentally, it may be said that Charles Darwin was a subscriber from the first to this publication.

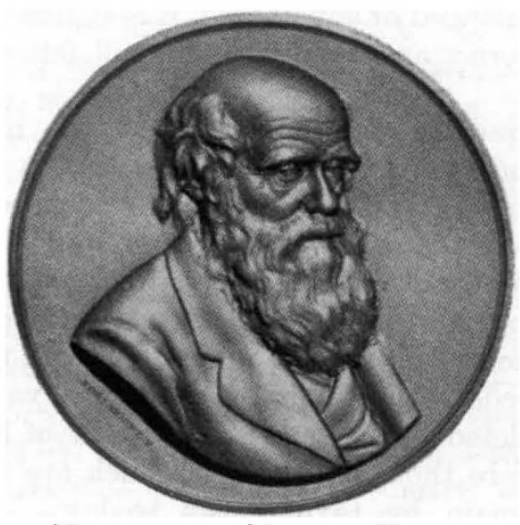

Darwin Medal of the Midland Union of Natural History SocIETIES.

Steps were taken to acquaint Darwin with the proposal and to ask his permission to adopt his name. Darwin replied as follows:

"I request that you will be so good as to inform the members of the Committee that their wish to name the medal after me is a very great honour, which I gladly accept. It is particularly pleasing to me to have my name connected, in however indirect a manner, with a scheme for advancing science-the study of which has been my chief source of happiness throughout life." 